\title{
Groundwater features in Hoedh el Chargui, Mauritania
}

\section{La risorsa idrica sotterranea nella regione dell'Hodh el Chargui, Mauritania}

\author{
Chiara Caselle, Manuela Lasagna, Sabrina Maria Rita Bonetto, Domenico Antonio De Luca, Stefano Bechis
}

Riassunto: L'Hodh el Chargui è una regione situata nel sud-est della Mauritania, a $1000 \mathrm{~km}$ dalla capitale Nouakchott, e risulta una delle zone più povere e remote del paese. É caratterizzata da severe condizioni climatiche ed ambientali con conflitti ed insicurezza alimentare sia nelle zone urbanizzate che in quelle rurali. L'agricoltura e la pastorizia costituiscono le principali attività economiche per la popolazione che dipende completamente dalle risorse naturali. A tal proposito è stato dedicato a questa area uno specifico studio dal titolo "Ridurre la vulnerabilità agro-pastorale e migliorare la resilienza in Hodh el Chargui”, nell'ambito del programma "Rafforzamento istituzionale in Mauritania verso la resilienza agricola e pastorale (RIMRAP)", finanziato dall'Unione Europea. Gli obiettivi del progetto sono il rafforzamento della resilienza delle comunità dell'Hodh el Chargui e la riduzione della loro vulnerabilità alle crisi, garantendo l'accesso alle risorse naturali e la loro sostenibilità. Tra queste, la risorsa idrica risulta di fondamentale e strategica rilevanza per assicurare lo sviluppo delle attività agricole e pastorali, la sicurezza alimentare ed adeguate condizioni sanitarie.

Keywords: groundwater; access to water; arid regions, participative approach, Mauritania.

Parole chiave: acque sotterranee, accesso all'acqua, regioni aride, approccio partecipativo, Mauritania.

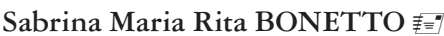

Department of Earth Science, University of Turin, Turin

sabrina.bonetto@unito.it

Chiara CASELLE, Manuela LASAGNA,

Domenico Antonio DE LUCA

Department of Earth Science, University of Turin, Turin

chiara.caselle@unito.it; manuela.lasagna@unito.it; domenico.deluca@unito.it;

\section{Stefano BECHIS}

Interuniversity Department of Regional and Urban Studies and Planning (DIST), Politecnico and University of Turin, Turin, Italy; stefano.bechis@unito.it

Ricevuto/Received: 18 November 2020-Accettato/Accepted: 21 December 2020 Pubblicato online/Published online: 30 December 2020

This is an open access article under the CC BY-NC-ND license:

http://creativecommons.org/licenses/by-nc-nd/4.0/

(C) Associazione Acque Sotterranee 2020
Il presente studio illustra i risultati di un censimento dei pozzi della regione dell'Hodh el Chargui, con particolare attenzione alla loro distribuzione sul territorio e alle principali caratteristiche della risorsa idrica sotterranea.

Abstract: : The Hodh el Chargui, a region located in the south-east of the Mauritania at $1000 \mathrm{~km}$ to the capital city of Nouakchott, is one of the poorer and remoter areas of the country. It is characterised by hard and in rural environment. Farmers and agro-pastoralists are the main economic actors and completely depend on natural resources. A specific project entitled "Reducing Agro-pastoral Vulnerability and Improving Resilience in Hodh el Chargui", funded by European Union, has been implemented in the Program "Institutional Strengthening in Mauritania towards Agricultural and Pastoral Resilience (RIMRAP)". The aims of the project are the strengthening of the resilience of Hodh el Chargui communities and the reduction of their vulnerability to crisis, assuring access to natural resources and their sustainable use. In particular, the water resource is fundamental to assure the development of the traditional agricultural and pastoral activities and guarantee proper health conditions.

The present study reports the results obtained from a census of the well in the Hodh el Chargui, their distribution in the region and the main features of groundwater resource.

\section{Introduction}

In several Sub-Saharan African countries, environmental conditions are often vulnerable to several stresses (climate, population growth, human activities impact, conflicts and insecurity), which may produce heavy effects on their development and the use of natural resources. In those areas, actions for protecting water and soil against desertification are incentivised and encouraged from Authorities and policy makers.

The analysis of territorial frameworks would be useful in assessing such interventions and defining the impacts of actions and policies to ensure local food security, social development and sustainable natural resources management. This information should be shared among local administrations, scientific community and any organisation that operates on areas of interest (Bonetto et al. 2015; Lasagna et al. 2015, Perotti et al. 2016; Bonetto et al. 2017; Dan-badjo et al. 2017).

In these environments, the frequent drought periods, the ephemeral nature of surface water and the poorness of natural resources often generate severe consequence for rural and agropastoral communities. In addition, the rural exodus of people 
from the countryside threatens the traditional mechanisms of development, maintenance and conservation of this fragile equilibrium between the environment and rural populations (Tiepolo et al. 2019; Fonjong et al. 2005).

An example of critical area is represented by the Hodh el Chargui region of the Mauritania. This region occupies the south-eastern sector of the Mauritania and is located about $1000 \mathrm{~km}$ east of the capital city, Nouakchott. It has an extension of about $182700 \mathrm{~km}^{2}$ (17.7\% of the total area of the country) and is divided in 7 administrative areas called "moughataas" (Amourj, Bassikonou, Djiguenni, Néma, Oualata, Timbedgha, N'Beikett Leouach). The lower territorial units are named "communes". In the Hodh el Chargui 31 communes are present and each of them is composed of many villages (Figure 1).

The area is mainly rural, being occupied by small villages where both nomadic and settled people live. Principal activities are pastoralism and, only secondarily, agriculture.

From a morphological point of view, the territory is characterised in the northeastern part by a plateau (Dhar Plateau), with maximum height of $420 \mathrm{~m}$ above sea level (a.s.l.). The western cliff of the plateau is a few tens of metres high and delimitates a large flat area with altitudes ranging between 150 and $250 \mathrm{~m}$ a.s.l. that corresponds to the liveliest and actively populated part of the region.
The area is strongly interested by sand dunes, especially in the north of the region, where the aeolian deposits may reach thicknesses of more than $100 \mathrm{~m}$. In the south of the region, the thickness of the surface deposits are lower and the deposits are mainly represented by fixed dunes extended in an ENE-WSW direction, that progressively leave place to the outcrops of rock basement (Bradley et al. 2015).

The surface water resources of the region mainly consist of wadis, which dry-up and turn in sanded riverbeds during the dry season. On the contrary, in case of intense rainfall, they can be interested by enlargements of the riverbed and erosion of the banks. Some small lakes form in the rainy season in the depressed areas, but just few of them are perennial.

The climate is characterised by a long dry season (from October to June) and short humid season (from July to September) with precipitations that may sometimes be violent and catastrophic.

Three types of physical environments are present: the arid desert in the northernmost part, the Sudano-Sahelian environment in a narrow sector to the south, close to the boundary with Mali, and the Sahelian one, covering the rest of the region. For this reason, rainfall decreases from south to north, ranging between $400 \mathrm{~mm} /$ year and $100 \mathrm{~mm} /$ year respectively. The temperatures have a high diurnal variability with a minimum of $12^{\circ} \mathrm{C}$ and a maximum of $46.6^{\circ} \mathrm{C}$, but the average temperatures are rather high, equal to $30^{\circ} \mathrm{C}-32{ }^{\circ} \mathrm{C}$,

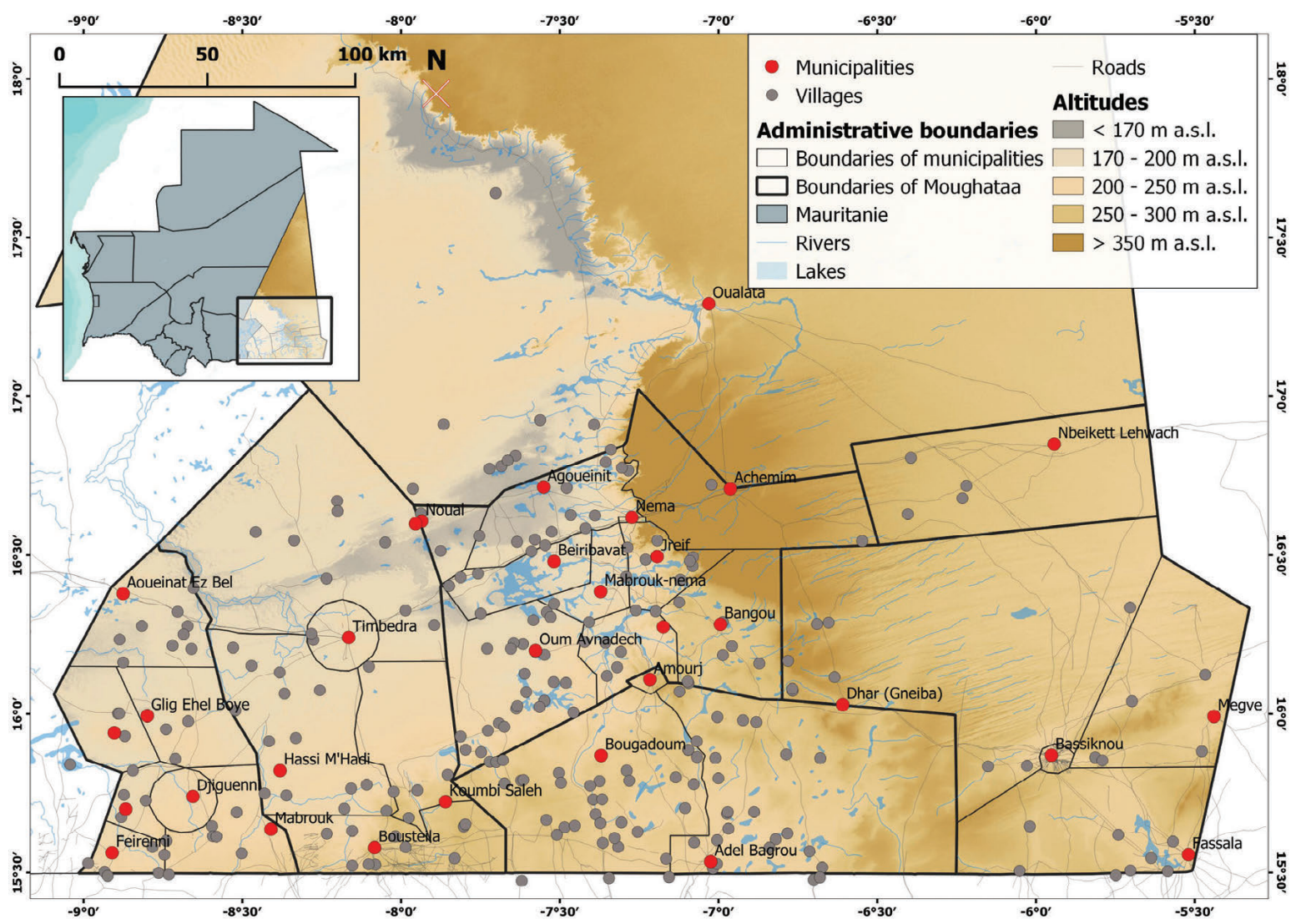

Fig. 1 - Geographic setting of the Hodh el Chargui region. Black line: boundaries of the Moughataas; red dots: Communes; black dots: villages with more than 300 inhabitants. Fig. 1 - Mappa della regione dell'Hodh el Chargui. Le linee nere indicano il confine delle "Moughataas", i punti rossi indicano i "Communes", i punti neri rappresentano i villaggi con più di 300 abitanti. 
with low annual variation (Bechis et al. 2018; Demarchi et al. 2018; Caselle et al. 2020)

A specific project entitled "Reducing Agro-pastoral Vulnerability and Improving Resilience in Hodh el Chargui" has been implemented in the Program "Institutional Strengthening in Mauritania towards Agricultural and Pastoral Resilience (RIMRAP)", funded by European Union. Specific attention has been paid to the groundwater resource: due to presence of ephemeral surface water and dry climate, it represents the primary resource for human and animal supply. The present paper aims to propose the results of the analysis of the water points distribution and water resource features in the Hodh el Chargui, in order to plan adequate actions to guarantee a sustainable access to irrigation and drinking water, reducing diseases and mortality and assuring food security.

\section{Geological and hydrogeological framework}

The studied area is located at the south-western corner of the Mauritania and, in particular, in the southern borders of the Taoudéni Basin, where 3 geological supergroups have been recognised (Bradley et al. 2015; Lahondere et al. 2005):

- the Adrar Supergroup (Upper Neoproterozoic - Upper Ordovician);

- the Dhar Supergroup (Ordovician Upper-Carboniferous);

- the Walata Supergroup (Upper Triassic-Cretaceous).

The Adrar and Dhar Supergroups are mainly composed of calcareous and terrigenous sedimentary rocks: dolostones, sandstones, mudstones, siltstones, argilites, shales (Neoproterozoic and Paleozoic Supracrustal Rocks). These units are mainly present in the central sector of the investigated area (from Agoueinit to the border with Mali).

The Walata Supergroup is represented by intrusions of gabbro, diorite, dolerite, microgabbro (Mesozoic Intrusive Rocks) outcropping in the central-southern sector of the area (Mabrouk, Amourj, Hassi Etile, Oum Avnadech). In the Dhar plateau, located east to the Nema region, this sequence is sealed with angular discordance by Cretaceous-Tertiary sedimentary units mainly constituted by ferricretes and detritic lateritites (close to the city of Nema) and sandstones and clays with precipitation of iron oxides (in the eastern sector, up to the Mali boundary with a thickness of few metres up to 15 metres).

Quaternary deposits are represented by sand, gravel and heterogenous deposits of fluvio - lacustrine origin, distributed in particular in the central sector of the investigated area, which represents an endoreic basin crossed by streams and ephemeral lakes. The other sectors are mainly covered by aeolian deposits with dunes morphologies (Fig. 2).

Based on hydraulic and lithological properties of rocks and sediments, the geological succession of the study area can be divided into three different hydrogeological units (Friedel et al. 2015).

The hydrogeological unit made of Neoproterozoic-Silurian sediments and Jurassic intrusive rocks (dolerites) shows a low permeability (PC2, Figure 3), locally increased by the presence of fractures and filonian bodies. It is generally considered as an aquitard.

The hydrogeological unit of the Cambrian and Ordovician (CO1 and CO2, Figure 3) are mainly constituted by sandstones and coarser sedimentary rocks with higher secondary permeability and represents an aquifer.

Finally, the Mesozoic and Quaternary hydrogeological unit (JQ, Figure 3) mainly consists of deposits and rocks belonging to the Walata Supergroup. It is divided into two complexes:

- the complex of sandstones (Jurassic and Cretaceous), particularly extended in the Dhar plateau and marked by a medium to high permeability just in case of low cementation or fractures.

- the complex of the Quaternary deposits, mainly represented by coarse sediments of various origin with high primary permeability, except for local lenses of lacustrine sediments. Due to their high permeability, these sediments represent aquifers. The aeolian sediments are the most extended and thick (from 20 to 100 metres); deposits of other origin have a less continuous distribution and may form aquifers with local significance, i.e. alluvial deposits fed by ephemeral streams.

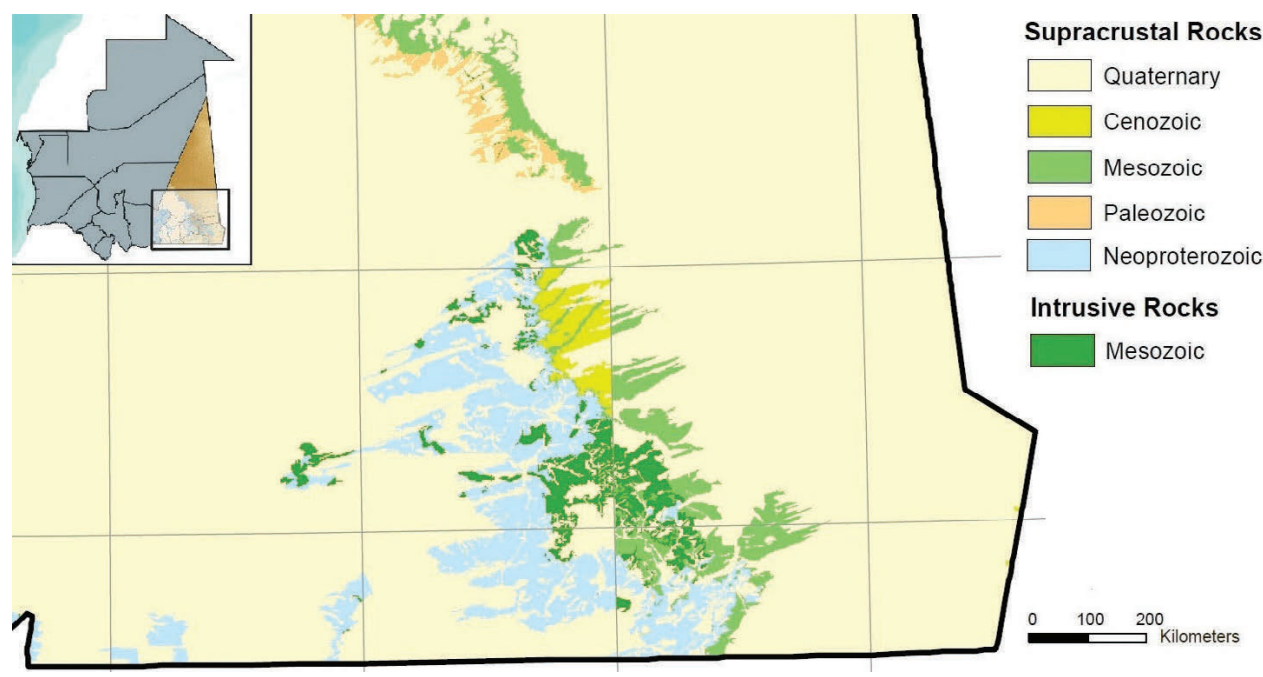

Fig. 2 - Geological and tectonic framework. of the Hodh el Chargui region. Supracrustal rocks include sedimentary, volcanic, and metamorphic rocks equivalents. (Bradley et al. 2015).

Fig. 2 - Schema geologico-strutturale della regione dell' Hodh el Chargui (Mauritania). Le rocce sopracrostali incudono rocce sedimentarie, vulcaniche e metamorfiche. (Bradley et al. 2015). 


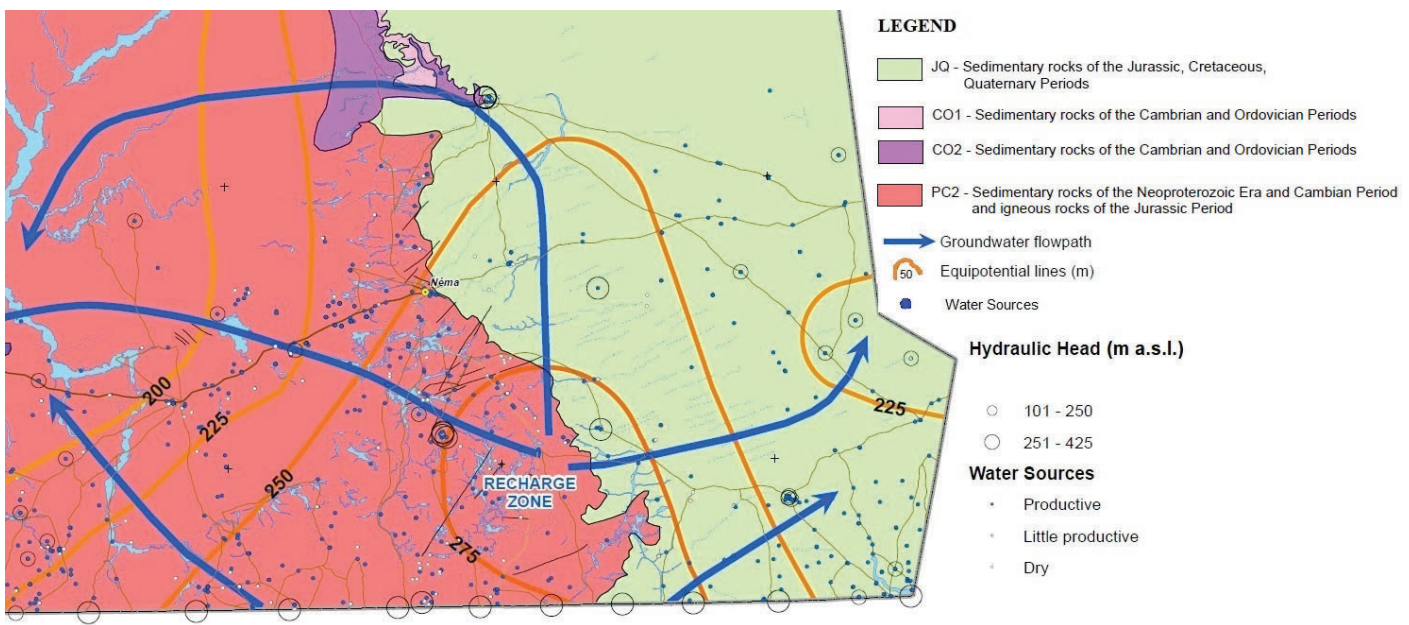

Fig. 3 - Detail of the Hydrogeological Map of Mauritania for the studied area (Friedel et al 2015).

Fig. 3 - Dettaglio della carta idrogeologica della Mauritania (Friedel et al. 2015) relativo all'area di studio.

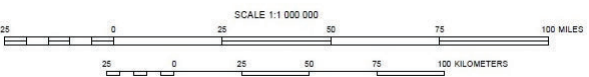

Based on the Geological map reported in Figure 2 and the Hydrogeologic map of Mauritania (Friedel et al. 2015), water sources in the studied area are mainly distributed in the JQ unit (eastern area) and in the PC2 unit (western area) (Fig. 3).

The abundance of groundwater resources is highly dependent on recharge. In the investigated area, the recharge of the aquifers, which comes from the southern sectors (corresponding more or less to the moughataa of Amourj), is almost totally ensured by underground feeding, which can be very slow (Friedel et al. 2015). The faster local recharge, provided by rainfall, is very low due to the arid climate and evapotranspiration.

\section{. Materials and Methods}

The beginning of the research was dedicated to the collection of the existing geological and hydrogeological data of the region, particularly with regard to water drilling campaigns realised in the region. The main sources of information were represented by:

- HEFEM Hydrogeological Reports (2006-2009) - Support to Rural Municipalities for Securing Water Management carried out by the NRD-Desertification Research Unit of the University of Sassari, Italy during 2006 and 2007 in the central area of Hodh el Chargui (Ghiglieri et al., Università di Sassari, unpublished data 2007; Ghiglieri and Carletti 2010).

- Official reports and thematic maps of the Second Institutional Strengthening Project of the Mining Sector of the Islamic Republic of Mauritania (PRISMAS II) carried out by the USGS on the entire Mauritania national territory during the 2000s (Friedel et al. 2008; Friedel et al. 2015; PRISM II).

Under the RIMRAP project, carried out in the period 20162018, an on-site survey was conducted with a participative approach involving people in the villages with at least 300 inhabitants (about 265 villages), in order to collect local information covering the entire region. A specific questionnaire was developed, including social, economic, climate and natural resources information (Caselle et al. 2020). A more specific set of questions was directed to investigate water availability and the features of water wells for a capillary reconstruction of the hydrogeological characteristics of the region. The collected information allows to integrate the available literature data on the wells of the region. Finally, some physical-chemical parameters ( $\mathrm{pH}$, Electrical Conductivity and temperature) were measured in situ with field instruments. The equipment for field measurements consisted in:

- $\quad$ handheld GPS instruments to locate points on a Landsat map through ArcPad;

- conductimeter (Hanna Instruments HI99300) to measure the water Electrical Conductivity (EC) $\left[\mu \mathrm{S} / \mathrm{cm}^{-1}\right]$ in the field;

- freatimeter to measure the groundwater table depth in the wells.

USGS Landsat imagery and Digital Elevation Models (DEMs) of the region were used and integrated in order to obtain a cartographic base for the visualisation and interpretation of the collected data.

\section{Results and discussion}

In the RIMRAP project, 105 water points distributed in the studied area were censed. Three types of water points were recognised:

- modern wells: hand dug wells with concrete walls;

- traditional wells: hand dug wells without casing (wall made of natural stones or other natural materials);

- drilled wells: mostly pump-equipped.

The most widely type of water source is the modern well ( $45 \%)$, followed by the drilled wells $(28 \%)$ and the traditional well $(27 \%)$. Most of them are used for domestic (drinking or washing water), livestock or agriculture uses at the same time.

Many of the communities have more than one water well in the neighbourhood. The distances between wells and villages range between 0 and 3000 metres; the average distance is about 350 metres. However, the absence of a controlled and 
scientific-based management and organisation of the number of wells, often affects their activity status.

Most of the 105 water points identified are functioning. Some traditional $(38 \%)$ and modern wells $(34 \%)$ resulted abandoned and just few boreholes (28\%) were not operative due to pump that was not working.

For most of the considered wells, the survey identified the existence of a season when wells get dry. Among the 105 identified wells, 83 have a dry-out period. This period is between April and August, i.e. in correspondence of the end of the long dry season. This phenomenon may be due to several reasons, e.g. the excessive water extraction, the long drought periods or the short distance and interference between the wells. Among the points that have a perennial flow, almost half are drilled wells. Therefore, drilled wells equipped with pump are a type of infrastructure that can guarantee continuity in water supply. They are randomly distributed in the area and are located both in the eastern and western areas of the region where Friedel et al. (2015) identified, respectively, the JQ and PC2 units.

With regard to the main physical-chemical features of the censed water points, the water temperature is particularly high due to the hot and arid climate, whereas the $\mathrm{EC}$ values range between 15 and $2798 \mu \mu \mathrm{cm}^{-1}$ (Table 1).

Surface structures to protect the water point are sometimes present; however, groundwater may have a rather high vulnerability to external agents coming from the ground (runoff water, rain or waste water) and air (objects, powder, etc.). In addition, the lack of water storage infrastructure (water tower and ground tank) is a strong criticality and can be a major problem for human and animal supply, especially in the dry season.

The RIMRAP project data were then integrated with the water points identified both by the PRISMAS II project (Friedel et al. 2015; PRISM II) (1040 water points widespread
Tab. 1 - Temperature and EC parameters (average, minimum and maximum values) collected during the water point census promoted by the RIMRAP project.

Tab. 1 - Valori medi, minimi e massimi di temperatura e conducibilità elettrolitica misurati nei pozzi censiti durante il progetto RIMRAP.

\begin{tabular}{|l|c|c|}
\cline { 2 - 3 } \multicolumn{1}{c|}{} & Temperature $\left[{ }^{\circ} \mathrm{C}\right]$ & $\begin{array}{c}\text { Electrical Conductivity } \\
{\left[\mu \mathrm{S} \mathrm{cm}^{-1}\right]}\end{array}$ \\
\hline Average value & 31.8 & 697 \\
\hline Maximum & 37.8 & 2798 \\
\hline Minimum & 25.9 & 15 \\
\hline
\end{tabular}

in the entire Hodh el Chargui) and the HEFEM project described above that cover a more limited area inside the Hodh el Chargui (450 water points). All information about water points distribution and features was analysed and reported in synthetic maps. Figure 4 reports the distribution of all water points identified.

The depth of the water points ranges between 120 metres and few metres. The minor depths $(<20 \mathrm{~m})$ were observed in the western and central sectors of the investigated area. In this sector, the aquifer appears more superficial and the groundwater is hosted in sediments of reduced thickness or in fractured rocks which guarantee more significant flows in the first tens of metres of depth. On the contrary, in the eastern area (the Dhar plateau), most water points have depths higher than 50 metres (Fig. 5).

Information about the static level of groundwater table at water points coming from the different projects can only be partially compared and integrated due to the differences in the seasons and period of measuring, type of aquifers monitored, scale of analysis and local morphology. However, the general trend is similar, suggesting two different hydrogeological units in the eastern and western sectors of the studied area with different groundwater flow direction, as reported by Friedel et al. (2015) (Figure 3).

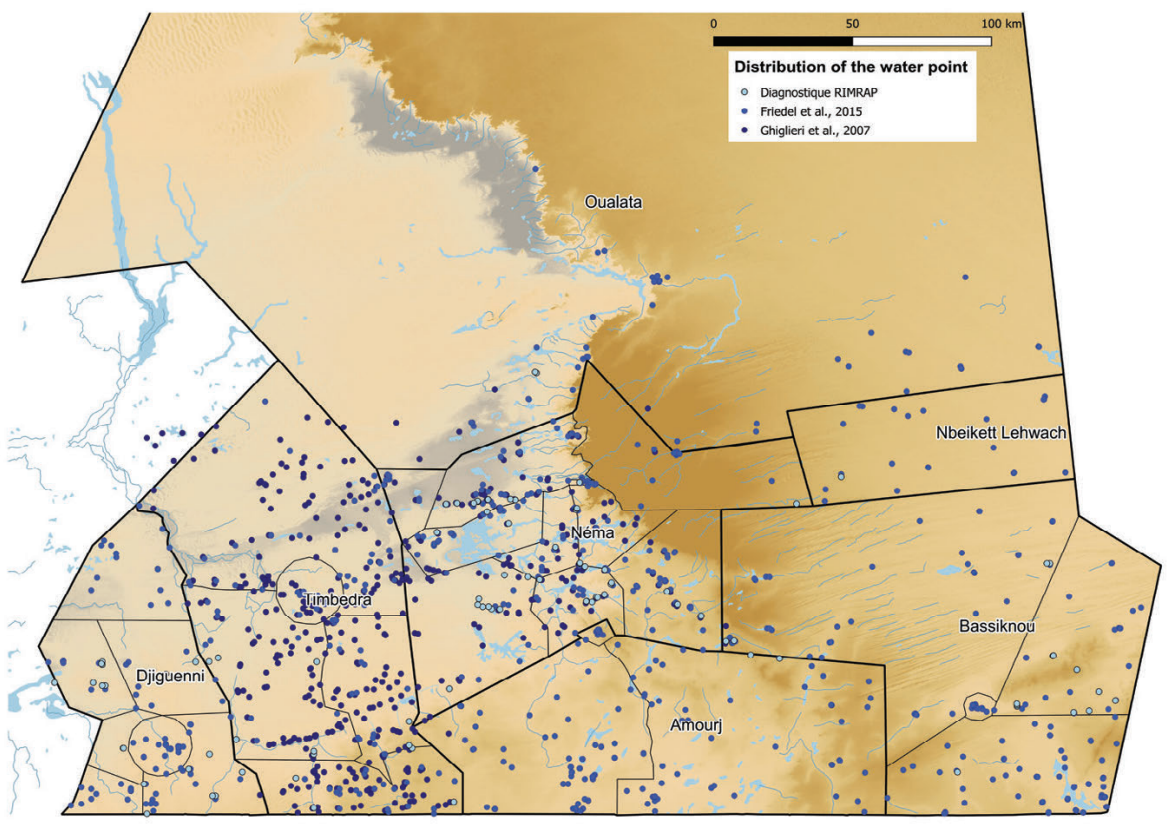

Fig. 4 - Distribution of water points identified by the HEFEM, PRISM II and RIMRAP projects.

Fig. 4 - Ubicazione dei punti acqua censiti nei progetti HEFEM, PRISM II e RIMRAP. 


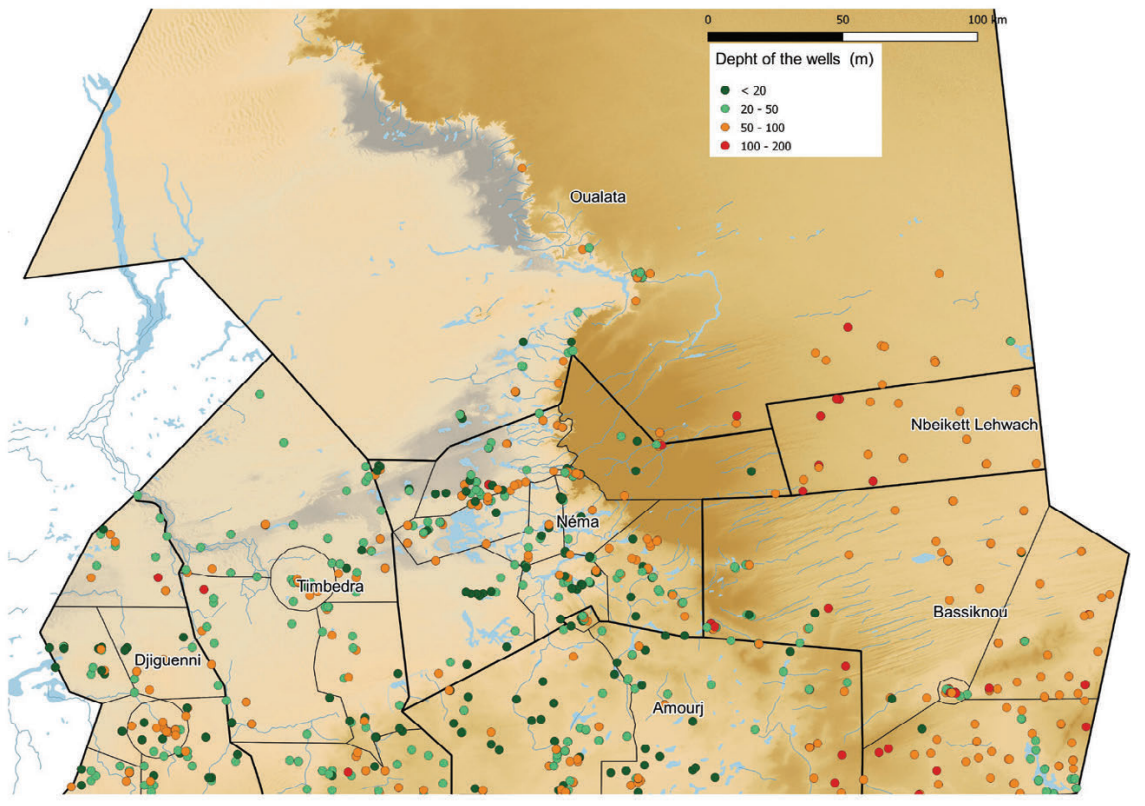

Fig. 5 - Depth of wells from RIMRAP and PRISM II projects.

Fig. 5 - Profondità di pozzi censiti nei progetti RIMRAP e PRISM II.
Most of the groundwater table depths are lower than 40 metres below ground level with a prevalence of wells characterised by groundwater table depths lower than $10 \mathrm{~m}$ below ground surface. However, the eastern sector (Bassiknou, Fassala) of the Dhar Plateau, characterised by Jurassic and Cretaceous sedimentary rocks and Quaternary deposits, shows groundwater table depth deeper than 40 metres, with less favourable conditions for groundwater extraction. The values are in general inhomogeneous and the geological variability is probably the cause of this unpredictability. The Quaternary deposits show differences as regard to the lateral continuity and thickness. Therefore, the aquifer can not form a continuous layer with uniform water static level and productivity. At the same time, the hard rocks of the bedrock are characterised by a heterogeneous degree and a network of fractures, and the circulation and extraction of water is conditioned by very local patterns. Consequently, it is possible that two adjacent wells intercept different aquifers, or different sectors of the same aquifer, showing different groundwater table depth (Figure 6).

With regard to the EC, data show a prevalence of low values, below $1000 \mu \mathrm{S} \mathrm{cm}^{-1}$, with just a few dozen points that present EC higher than $5000 \mu \mathrm{S} \mathrm{cm}^{-1}$ (Fig. 7). In particular, in the eastern sector (Dhar plateau) the values are very low, below $100 \mu \mathrm{S} \mathrm{cm}$, with minimum anomalous values of few tens of $\mu \mathrm{S} \mathrm{cm}^{-1}$, typical of rainwater. In the western and central

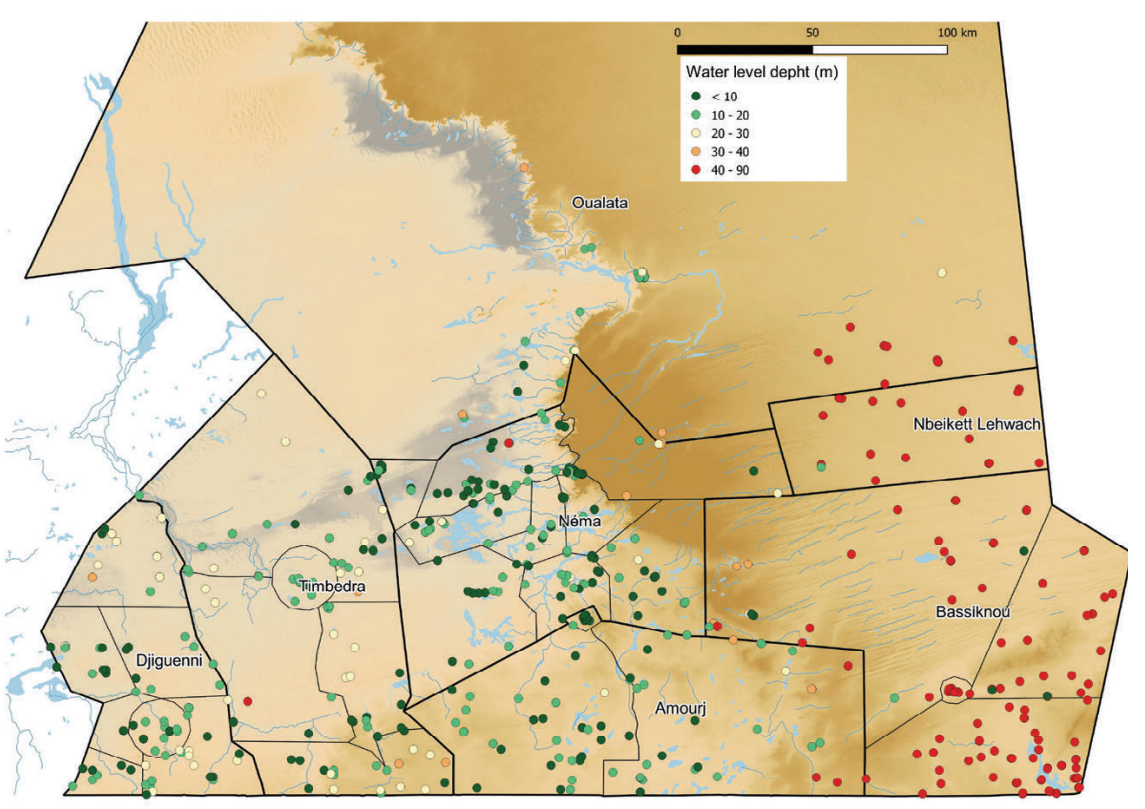

Fig. 6 - Groundwater table depht in wells from RIMRAP and PRISM II projects.

Fig. 6 - Soggiacenza misurata in pozzi censiti nei progetti RIMRAP e PRISM II. 


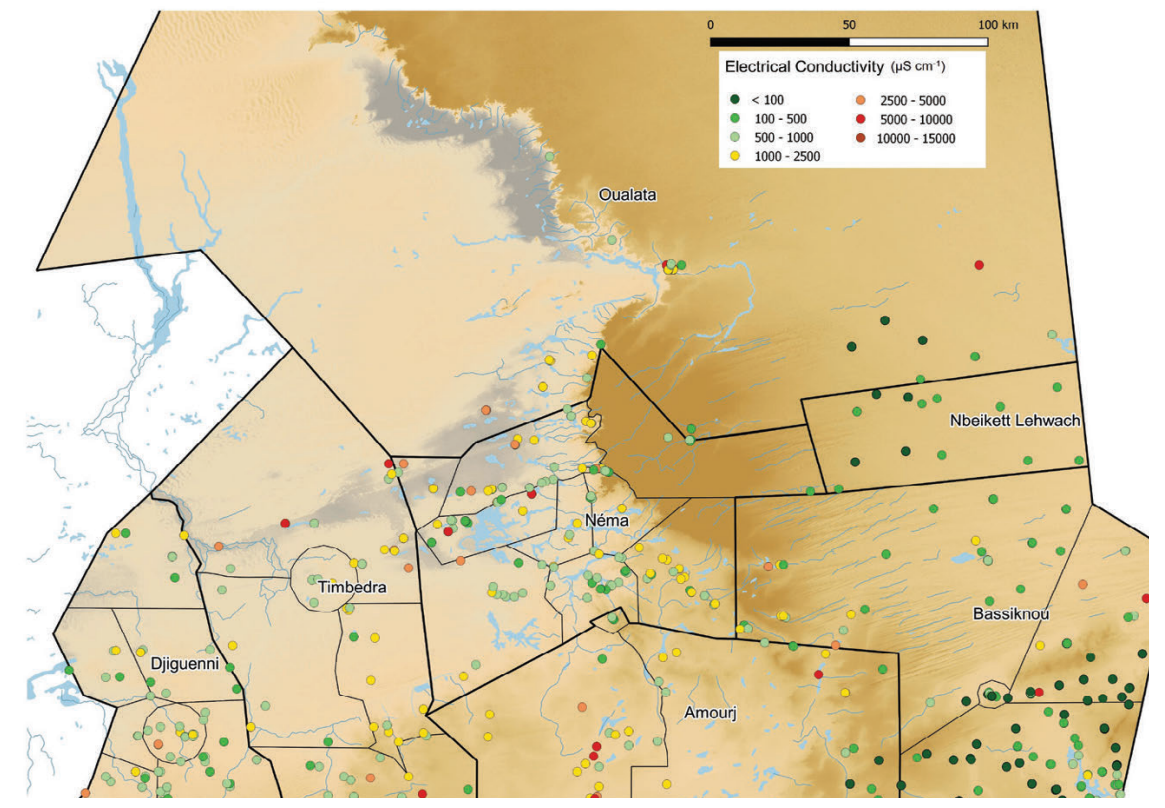

Fig. 7 - EC values measured in wells from RIMRAP and PRISM II projects.

Fig. 7 - Valori di EC misurati in pozzi censiti nei progetti RIMRAP e PRISM II. sectors EC shows values between 1000 and $2500 \mu \mathrm{S} \mathrm{cm} \mathrm{cm}^{-1}$. Based on the collected data and the integration with previous studies, local salinity problems are evident, especially in the central sector (Touil, Noual, Timbedra, Beribave, Walata) where there are various points that show EC values between 5000 and $15000 \mu \mathrm{S} \mathrm{cm} \mathrm{cm}^{-1}$. In general, it has been observed that in the Dhar Plateau (eastern sector) the wells are deeper and EC values are lower, whereas opposite conditions (shallow wells and higher EC value) are present in the lowland (western sector). Similar statement can be also applied concerning the groundwater table depth and EC values distribution. As observed in Figure 6 and 7, higher EC values (up to 2300 $\mu \mathrm{S} / \mathrm{cm}^{-1}$ ) are mainly associated to the wells with lower groundwater table depth $(<30 \mathrm{~m})$ which characterise the western sector; the wells with deeper groundwater table depth (> 30m), which are located in the eastern sector, show lower EC values $\left(<700 \mu \mathrm{S} / \mathrm{cm}^{-1}\right)$ (Fig. 8). Due to the difference in the $\mathrm{EC}$ value between the eastern and western sectors, which correspond to different hydrogeological units according to Friedel et al. 2015, it can be supposed a relationship between salinity, hydrogeological units and the arid environment. In particular, salinity problems were observed in correspondence of lower groundwater table depth, in association to arid conditions. No direct correlation with population density or transhumance corridor were observed.

For human use, no WHO health-based guideline value was established; however, a value of $2500 \mu \mathrm{S} \mathrm{cm}-1$ at $20^{\circ} \mathrm{C}$ is indicated in WHO Directive (WHO 2006; WHO 2017), as a suggested limit. For animals, a generally higher salt content is accepted, with a maximum values between 5000 et 10000 $\mu \mathrm{S} \mathrm{cm} \mathrm{cm}^{-1}$, depending on the type of animal.

The majority of water wells present discharge values lower than $10 \mathrm{~m}^{3} / \mathrm{h}$. Those wells with discharge higher than $20 \mathrm{~m}^{3} / \mathrm{h}$ are mostly associated to modern and drilled wells, but the general distribution of the values does not appear related either to the typology or to the depth of the water point (Fig. 9).

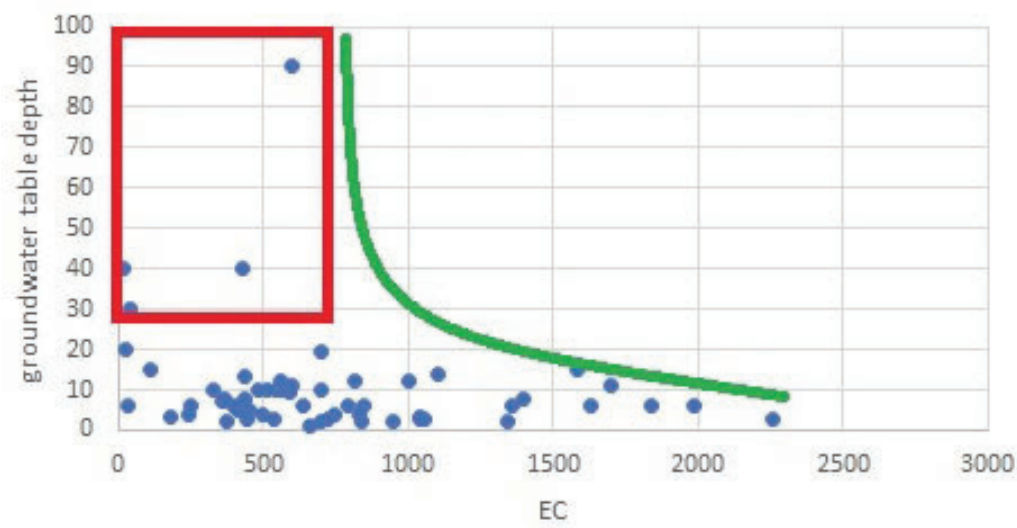

Fig. 8 - EC value vs groundwater table depth. The lower EC values $\left(<700 \mu \mathrm{s} / \mathrm{cm}^{-1}\right)$ are always in association with higher groundwater table depth $(>30 \mathrm{~m})$ (red square), whereas in correspondence of lower groundwater table depth $(<30 \mathrm{~m})$ the EC range from low to very high values (up to $2300 \mu \mathrm{s} / \mathrm{cm}^{-1}$ ). The green line represents the distribution curve of the EC values in relation to different groundwater table depht.

Fig. 8 - Relazione tra valori di EC e livello piezometrico. I valori più bassi di CE si registrano in corrispondenza ai pozzi caratterizzati da livello piezometrico più profondo (>30m) (rettangolo rosso), mentre in corrispondenza a livelli piezometrici più superficiali si osservano valori di EC da bassi a molto alti (fino a $2300 \mu \mathrm{s} / \mathrm{cm}^{-1}$ ). La linea verde rappresenta la distribuzione dei valori di EC in relazione alle differenti profondità della superficie piezometrica. 


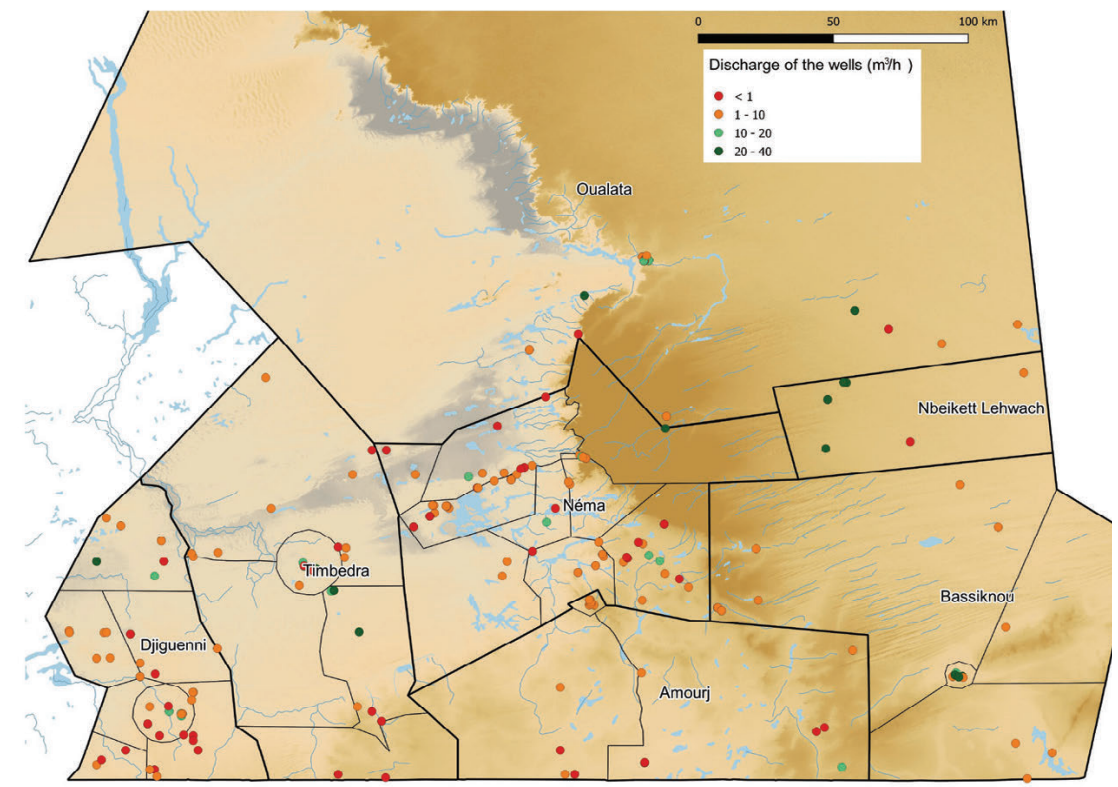

Fig. 9 - Discharge value in wells from RIMRAP and PRISM II projects.

Fig. 9 - Valori di portata registrati in pozzi censiti nei progetti RIMRAP e PRISM II.

\section{Conclusion}

The availability of water resources in the Hodh el Chargui mainly depends on the groundwater due to the absence of perennial surface water.

Despite the environmental, climatic and logistic features of the investigated area, a quite abundant existing data and new information have been collected about the groundwater resources of the region. Most of the censed water points are traditional wells which are not able to give continuity on water supply. From a geographical point of view, clear differences in groundwater table depth can be recognised between the eastern and the western parts of the region. This situation is coherent with the hydrogeological conceptual model proposed by Friedel et al 2015. The higher depths registered in the eastern area correspond to aquifers hosted in the Jurassic dolerites and Cretaceous sandstones of the Dhar plateau (Mesozoic hydrogeological unit). The low groundwater table depth and the inhomogeneous distribution of the measure in the western area confirm the existence of multiple aquifers within the recent aeolian and alluvial deposits (Quaternary hydrogeological unit), with a higher geological variability. As a consequence, in the Dhar plateau (eastern sector of the investigated area) the high groundwater table depth requires economic efforts in order to drill deep wells that need pumps and constant maintenance.

Moreover, the available information indicates a general low productivity of the wells and an inhomogeneity in the discharge values. The situation becomes more critical in particularly for the dry season, when many wells get dry. Only drilled wells equipped with pumps ensure a high and continuous discharge over time. Therefore, the withdrawn groundwater may be insufficient for the needs of the population, agriculture and livestock.
The EC values provide important information about the salinity and, consequently, the drinkability of groundwater or use for other purposes.

Even if the majority of the surveyed wells show values lower than $2500 \mu \mathrm{S} \mathrm{cm}^{-1}$, the maximum value registered in the area is very high, up to $15000 \mu \mathrm{S} \mathrm{cm}^{-1}$ (i.e. not acceptable values, not even for animals). These anomalously high values are randomly present in the whole region and no direct correlation with population density or transhumance corridor were observed. The absence of a clear distribution probably is due to the poor lateral continuity of the water bodies, Anyway, in general, it has been observed that in the Dhar Plateau (eastern sector) the wells are deeper and EC values are lower, whereas opposite conditions (shallow wells and higher EC value) are present in the lowland (western sector). Therefore, it can be supposed a relationship between salinity the presence of different hydrogeological unitsand the depths of wells and grounwater table depth, hydrogeological units and arid environment.

Lastly, the frequent absence of infrastructures to protect the water points makes them more vulnerable to contamination from external agents.

Acknowledgment and Funding: This research was funded by the European Project "Renforcement Institutionnel en Mauritanie vers la Résilience Agricole et Pastorale" (RIMRAP) - Financement de la Commission Européenne: 11e Fonds européen de développement. Référence: FED/137269/ACT/MR - Contract nº FED/2016/373942: "Reduction de la vulnérabilité Agropastorale et amélioration de la résilience dans le Hodh de Chargui". The authors thank Terre Solidali Onlus for the contribution in the on-site activities. 


\section{REFERENCES}

Bechis S, Bonetto S, Bucci A, Canone D, Cristofori E, De Luca DA, Demarchi A, Garnero G, Guerreschi P, Lasagna M. (2018) Improving governance of access to water resources and their sustainable use in Hodh el Chargui communities (South East Mauritania). 20 th EGU General Assembly 2018, 4-13 April 2018 (Vienna, Austria). Geophysical Research Abstracts Vol. 20, p. 15888. EGU2018-15888-1.

Bonetto S, Facello A, Cristofori EI, Camaro W, Demarchi A (2016) An Approach to Use Earth Observation Data as Support to Water Management Issues in the Ethiopian Rift, Climate Change Adaptation In Africa: Fostering Resilience And Capacity To Adapt, Climate Change Management, pp. 357-374.. ISSN 1610-2010 ISBN 978-3-319-49519-4 DOI 10.1007/978-3-319-49520-0

Bonetto S, De Luca DA, Lasagna M.; Lodi, R. (2015) Groundwater Distribution and Fluoride Content in the West Arsi Zone of the Oromia Region (Ethiopia). In Proceedings of the Engineering Geology for Society and Territory - Volume 3; Lollino G, Arattano M, Rinaldi M, Giustolisi O, Marechal JC, Grant GE, Eds.; Springer International Publishing: Cham; pp. 579-582.

Bonetto S, Facello A, Cristofori EI, Camaro W, Demarchi A (2017) An Approach to Use Earth Observation Data as Support to Water Management Issues in the Ethiopian Rift, Climate Change Adaptation In Africa: Fostering Resilience And Capacity To Adapt, Climate Change Management, pp. 357-374. ISSN 1610-2010 ISBN 978-3-319-49519-4 DOI 10.1007/978-3-319-49520-0

Bradley DC, Motts H, Horton JD, Giles S, Taylor CD (2015) Geologic map of Mauritania (phase V, deliverable 51a, 51b and 51c), chap. A1 of Taylor, C.D., ed., Second projet de renforcement institutionnel du secteur minier de la République Islamique de Mauritanie (PRISM-II): U.S. Geological Survey Open-File Report 2013-1280-A1, 3pl., http://dx.doi. org/10.3133/ofr20131280.

Dan-badjo AT, Diadie HO, Bonetto SMR, Semita C, Cristofori EI, Facello A (2017) Using Improved Varieties of Pearl Millet in Rainfed Agriculture in Response to Climate Change: A Case Study in the Tillabéri Region in Niger. In Climate Change Research at Universities: Addressing the Mitigation and Adaptation Challenges; Leal Filho, W., Ed.; Springer International Publishing: Cham, 2017; pp. 345-358. ISBN 978-3-319-58214-6.

Caselle C, Bonetto S, De Luca DA, Lasagna L, Perotti L, Bucci A, Bechis S. (2020) An Interdisciplinary Approach to the Sustainable Management of Territorial Resources in Hodh el Chargui, Mauritania. Sustainability 12(12), 5114, https:/doi. org/10.3390/su12125114

Demarchi A, Bechis S, Perott L, Garnero G, Isotta Cristofori E, Alunno L, Facello A, Semita C, Bonetto S, Guerreschi P (2018) An interdisciplinary approach to the analysis of agro pastoral resilience 481 in the Hodh el Chargui region (Mauritania). 20th EGU General Assembly 2018, 4-13 April 2018 (Vienna, Austria) Geophysical Research Abstracts, Vol. 20, p.15808. EGU2018-15808-1

Fonjong LN, Emmanuel NN, Fonchingong CC (2005) Rethinking the contribution of indigenous management in small-scale water provision among selected rural communities in Cameroon. Environ Dev Sustain, 2015, 6, 429-451, doi:10.1007/s10668-005-0501-3.
Friedel M J (2008) Inventory and review of existing PRISM hydrogeologic data for the Islamic Republic of Mauritania, Africa. US Geol. Survey Open File Report 2008-1138.; https:// pubs.usgs.gov/of/2008/1138/

Friedel MJ, Finn CA, Horton JD (2015) Hydrogeologic map of the Islamic Republic of Mauritania (phase V, deliverable 56), Synthesis of hydrologic data (deliverable 57), and chemical hydrologic map of the Islamic Republic of Mauritania (added value), chap. C of Taylor, C.D., ed., Second projet de renforcement institutionnel du secteur minier de la République Islamique de Mauritanie (PRISM-II): U.S. Geological Survey Open-File Report 2013-1280-C, 23 p., 2 pl., scale 1:1,000,000, http://dx.doi.org/10.3133/ofr20131280.

Ghiglieri G, Carletti A (2010) Integrated approach to choosing suitable areas for the realization of productive wells in rural areas of sub-Saharan Africa. Hydrological Sciences Journal, 2010, 55, 1357-1370, doi:10.1080/02626667.2010.527845.

HEFEM (2006-2009) Appui aux municipalités rurales pour la sécurisation et la gestion de l'eau "Support for Rural Municipalities to water safety and management." Available from: http:// www.projet-hefem.org:8080/servlet/ae5Mau (http://www. projet-hefem.org:8080/servlet/ae5Mau).

Lahondere D, Roger J, Le Metour J, Donzeau M, Guillocheau F, Helm C, Thieblemont D, Cocherie A. Guerrot C (2005) Notice explicative des cartes géologiques à 1/200,000 et 1/500,000 de l'extrême sud de la Mauritanie "Explanatory note for 1/200,000 and 1/500,000 from the extreme south of Mauritania". DMG, Ministère des Mines et de l'Industrie, Nouakchott, Rapport BRGM/RC-54273-FR.

Lasagna M, Dino GA, Perotti L, Spadafora F, De Luca DA, Yadji G, Dan-Badjo AT, Moussa I, Harouna M, Konaté M (2015) Georesources and Environmental Problems in Niamey City (Niger): A Preliminary Sketch. Energy Procedia 2015, 76, 67-76, doi:10.1016/j.egypro.2015.07.848.

Perotti L, Dino GA, Lasagna M, Moussa K, Spadafora F, Yadji G, Dan-Badjo AT, De Luca DA (2016) Monitoring of Urban Growth and its Related Environmental Impacts: Niamey Case Study (Niger). Energy Procedia, 2016, 97, 37-43, doi:10.1016/j.egypro.2016.10.014.

PRISM-II Second Projet de Renforcement Institutionnel du Secteur Minier de la République Islamique de Mauritanie "Second Institutional Project of the Mining Sector of the Islamic Republic of Mauritania", Phase V Available online: https://pubs. er.usgs.gov/publication/ofr20131280.

Tiepolo M, Bacci M, Braccio S, Bechis S (2019) Multi-Hazard Risk Assessment at Community Level Integrating Local and Scientific Knowledge in the Hodh Chargui, Mauritania. Sustainability 2019, 11, 5063, doi:10.3390/su11185063.

WHO (World Health OrganisationOrganisation) (2006) Guidelines for Drinking-Water Quality. First addendum to 3rd edn, vol. 1. Recommendations. Geneva: World Health OrganisationOrganisation.

WHO (World Health OrganisationOrganisation) (2017) Drinking Water Parameter Cooperation Project. Support to the revision of Annex I Council Directive 98/83/EC on the Quality of Water Intended for Human Consumption (Drinking Water Directive) - Recommendations. 2017 